ҚАЗАҚСТАН РЕСПУБЛИКАСЫ

ҰЛТТЫҚ ҒЫЛЫМ АКАДЕМИЯСЫНЫН

АБАЙ АТЫНДАҒЫ ҚАЗАҚ ҰЛТТЫҚ

ПЕДАГОГИКАЛЫҚ УНИВЕРСИТЕТІНІҢ

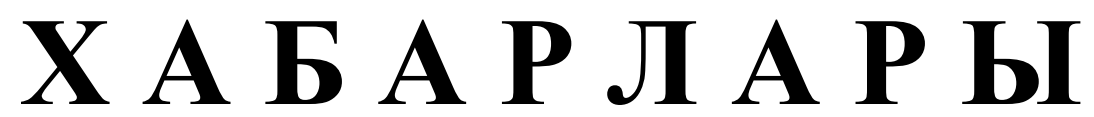

\section{ИЗВЕСТИЯ}

НАЦИОНАЛЬНОЙ АКАДЕМИИ НАУК РЕСПУБЛИКИ КАЗАХСТАН

КАЗАХСКИЙ НАЦИОНАЛЬНЫЙ

ПЕДАГОГИЧЕСКИЙ УНИВЕРСИТЕТ ИМ. АБАЯ

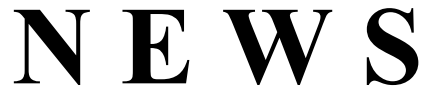

OF THE NATIONAL ACADEMY OF SCIENCES OF THE REPUBLIC OF KAZAKHSTAN

ABAY KAZAKH NATIONAL PEDAGOGICAL UNIVERSITY

ҚОҒАМДЫҚ ЖӘНЕ ГУМАНИТАРЛЫҚ ҒЫЛЫМДАР СЕРИЯСЫ

СЕРИЯ ОБЩЕСТВЕННЫХ И ГУМАНИТАРНЫХ НАУК

$\checkmark$

SERIES OF SOCIAL AND HUMAN SCIENCES

$$
5 \text { (321) }
$$

КЫРКУЙЕК - КАЗАН 2018 ж.

СЕНТЯБРЬ - ОКТЯБРЬ 2018 Г.

SEPTEMBER - OCTOBER 2018

1962 ЖЫЛДЫҢ ҚАНТАР АЙЫНАН ШЫҒА БАСТАҒАН

ИЗДАЕТСЯ С ЯНВАРЯ 1962 ГОДА

PUBLISHED SINCE JANUARY 1962

ЖЫЛЫНА 6 РЕТ ШЫҒАДЫ

ВЫХОДИТ 6 РАЗ В ГОД

PUBLISHED 6 TIMES A YEAR 
Ба с ре дактор

ҚР ҰҒА кұрметті мүшесі

Балықбаев Т.O.

Р е д а ц и я а лқ а сы:

экон. ғ. докторы, проф., ҚР ҰҒА академигі Баймұратов У.Б.; тарих ғ. докторы, проф., ҚР ҰҒА академигі Байпақов К.М.; филос. ғ.докторы, проф., ҚР ҰҒА академигі Есім Г.Е.; фил. ғ. докторы,, проф., ҚР ҰҒА академигі Қирабаев С.С.; эк. ғ. докторы, проф., ҚР ҰҒА академигі Кошанов А.К.; эк.ғ. докторы, проф., ҚР ҰҒА академигі Нәрібаев К.Н. (бас редактордың орынбасары); филос. ғ.докторы, проф., ҚР ҰҒА академигі Нысанбаев А.Н.; заң ғ. докторы, проф., ҚР ҰҒА академигі Сәбікенов С.Н.; заң ғ. докторы, проф., ҚР ҰҒА академигі Сүлейменов М.К.; эк. ғ. докторы, проф., ҚР ҰҒА академигі Сатыбалдин С.С.; тарих ғ. докторы, проф., ҚР ҰҒА академик Әбжанов Х.М.; тарих ғ. докторы, проф., ҚР ҰҒА корр. мүшесі Әбусеитова М.Х.; тарих ғ. докторы, проф., ҚР ҰҒА академик Байтанаев Б.А.; филол. ғ. докторы, проф., ҚР ҰҒА корр. мүшесі Жақып Б.А.; фил. ғ. докторы, проф., академик НАН РК Қалижанов У.К.; филол. ғ. докторы, проф., ҚР ҰҒА академик Қамзабекұлы Д.; тарих ғ. докторы, проф., ҚР ҰҒА академик Қожамжарова Д.П.; тарих ғ. докторы, проф., ҚР ҰҒА академик Койгелдиев М.К.; фил. ғ. докторы, проф., ҚР ҰҒА корр. мүшесі Кұрманбайұлы Ш.; тарих ғ. докторы, проф., ҚР ҰҒА корр. мүшесі Таймағанбетов Ж.К.; социол. ғ. докторы, проф., ҚР ҰҒА корр. мүшесі Шәукенова 3.К.; фил. ғ. докторы, проф., КР ҰҒА корр. мүшесі Дербісәлі А.; саяси. ғ. докторы, проф., Бижанов А.К., тарих ғ. докторы, проф., Кабульдинов 3.Е.; фил. ғ. докторы, проф., ҚР ҰҒА корр мүшесі Қажыбек Е.3.

\section{Р едакция ке н е с i:}

Молдова Республикасының ҰҒА академигі Белостечник Г. (Молдова); Әзірбайжан ҰҒА академигі Велиханлы Н. (Азербайджан); Тәжікстан ҰҒА академигі Назаров Т.Н. (Тәжікстан); Молдова Республикасының ҰҒА академигі Рошка А. (Молдова); Молдова Республикасының ҰҒА академигі Руснак Г. (Молдова); Әзірбайжан ҰҒА корр. мүшесі Мурадов Ш. (Әзірбайжан); Әзірбайжан ҰҒА корр. мүшесі Сафарова 3. (Әзірбайжан); э. ғ. д., проф. Василенко В.Н. (Украина); заң ғ. докт., проф. Устименко В.А. (Украина)

«Қазақстан Республикасы Ұлттық ғылым академиясының Хабарлары. Қоғамдық және гуманитарлық ғылымдар сериясы». ISSN 2224-5294

Меншіктенуші: «Қазақстан Республикасының Ұлттық ғылым академиясы» РҚБ (Алматы қ.)

Қазақстан республикасының Мәдениет пен ақпарат министрлігінің Ақпарат және мұрағат комитетінде 30.04.2010 ж. берілген № 10894-Ж мерзімдік басылым тіркеуіне қойылу туралы куәлік

Мерзімділігі: жылына 6 рет.

Тиражы: 500 дана.

Редакцияның мекенжайы: 050010, Алматы қ., Шевченко көш., 28, 219 бөл., 220, тел.: 272-13-19, 272-13-18, http://nauka-nanrk.kz. social-human.kz

(C) Қазақстан Республикасының Ұлттық ғылым академиясы, 2018

Типографияның мекенжайы: «Аруна» ЖК, Алматы қ., Муратбаева көш., 75. 
Главный редакто $p$

Почетный член НАН РК

T.O. Балыкбаев

Р е дак ци онн а я коллег и я:

докт. экон. Н., проф., академик НАН РК У.Б. Баймуратов; докт. ист. н., проф., академик НАН РК К.М. Байпаков; докт. филос. Н., проф., академик НАН РК Г.Е. Есим; докт. фил. Н., проф., академик НАН РК С.С. Кирабаев; докт. экон. Н., проф., академик НАН РК А.К. Кошанов; докт. экон. Н., проф., академик НАН РК К.Н. Нарибаев (заместитель главного редактора); докт. филос. н., проф., академик НАН РК А.Н. Нысанбаев; докт. юр. Н., проф., академик НАН РК С.Н. Сабикенов; докт. юр. н., проф., академик НАН РК М.К. Сулейменов; докт. экон. Н., проф., академик НАН РК С.С. Сатубалдин; докт. ист. н., проф., академик НАН РК Х.М. Абжанов; докт. ист. н., проф., чл.-корр. НАН РК М.Х. Абусеитова; докт. ист. н., проф., академик НАН РК Б.А. Байтанаев; докт. фил. н., проф., чл.-корр. НАН РК Б.А. Жакып; докт. фиолол. н., проф., академик НАН РК У.К. Калижанов; докт. фил. н., проф., академик НАН РК Д. Камзабекулы; докт. ист. н., проф., академик НАН РК Д.П. Кожамжарова; докт. ист. н., проф., академик НАН РК М.К. Койгельдиев; докт. филол. н., проф., чл.-корр. НАН РК Ш. Курманбайулы; докт. ист. н., проф., чл.корр. НАН РК Ж.К. Таймаганбетов; докт. социол. н., проф., чл.-корр. НАН РК З.К. Шаукенова; д. филол. н., проф., чл.-корр. НАН РК А. Дербисали; доктор политических наук, проф., Бижанов А.К.; доктор ист. наук, проф., Кабульдинов 3.Е.; доктор филол. н., проф., член-корр. НАН РК Қажыбек Е.3.

Р е дак ци онны й с ов е т

академик НАН Республики Молдова Г. Белостечник (Молдова); академик НАН Азербайджанской Республики Н. Велиханлы (Азербайджан); академик НАН Республики Таджикистан Т.Н. Назаров (Таджикистан); академик НАН Республики Молдова А. Рошка (Молдова); академик НАН Республики Молдова Г. Руснак (Молдова); чл.-корр. НАН Азербайджанской Республики Ш. Мурадов (Азербайджан), член-корр. НАН Азербайджанской Республики 3.Сафарова (Азербайджан); д. э. н., проф. В.Н. Василенко (Украина); д.ю.н., проф. В.А. Устименко (Украина)

Известия Национальной академии наук Республики Казахстан. Серия общественных и гуманитарных наук. ISSN 2224-5294

Собственник: РОО «Национальная академия наук Республики Казахстан» (г. Алматы)

Свидетельство о постановке на учет периодического печатного издания в Комитете информации и архивов

Министерства культуры и информации Республики Казахстан № 10894-Ж, выданное 30.04.2010 г.

Периодичность 6 раз в год

Тираж: 500 экземпляров

Адрес редакции: 050010, г. Алматы, ул. Шевченко, 28, ком. 219, 220, тел. 272-13-19, 272-13-18, www:nauka-nanrk.kz / social-human.kz

(C) Национальная академия наук Республики Казахстан, 2018 г.

Адрес типографии: ИП «Аруна», г. Алматы, ул. Муратбаева, 75

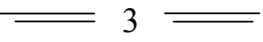


Chief Editor

\section{Honorary member of NAS RK \\ Balykbayev T.O}

Editorial board:

Doctor of economics, prof, academician of NAS RK Baimuratov U.B.; doctor of history, prof, academician of NAS RK Baipakov K.M.; doctor of philosophy, prof, academician of NAS RK Esim G.E.; doctor of philology, prof, academician of NAS RK Kirabayev S.S.; doctor of economics, prof, academician of NAS RK Koshanov A.K.; doctor of economics, prof, academician of NAS RK Naribayev K.N. (deputy editor-in-chief); doctor of philosophy, prof, academician of NAS RK Nyssanbayev A.N.; doctor of law, prof, academician of NAS RK Sabikenov S.N.; doctor of law, prof, academician of NAS RK Suleymenov M.K.; doctor of economy, prof, academician of NAS RK Satybaldin S.S.; doctor of history, prof, academician of NAS RK Abzhanov H.M; doctor of history, prof, corresponding member of NAS RK Abuseitova M.H.; doctor of history, prof, academician of NAS RK Baitanaev B.A.; doctor of philology, prof, corresponding member of NAS RK Zhakyp B.A.; doctor of philology, prof, academician of NAS RK Kalizhanov U.K.; doctor of philology, prof, academician of NAS RK Hamzabekuly D.; doctor of history, prof, academician of NAS RK Kozhamzharova D.P.; doctor of history, prof, academician of NAS RK Koigeldiev M.K.; doctor of philology, prof, corresponding member of NAS RK Kurmanbaiuly Sh.; doctor of history, prof, academician of NAS RK Taimaganbetov J.K.; doctor of sociology, prof, corresponding member of NAS RK Shaukenova Z.K.; doctor of philology, prof, corresponding member of NAS RK Derbisali A.; doctor of political science, prof Bizhanov A.K; doctor of History, prof Kabuldinov Z.E.; doctor of philology, prof, corresponding member of NAS RK Kazhybek E.Z.

\section{Editorial staff:}

Academician NAS Republic of Moldova Belostechnik.G (Moldova); Academician NAS Republic of Azerbaijan Velikhanli N. (Azerbaijan); Academician NAS Republic of Tajikistan Nazarov T.N. (Tajikistan); Academician NAS Republic of Moldova Roshka A. (Moldova) Academician NAS Republic of Moldova Rusnak G. (Moldova); Corresponding member of the NAS Republic of Azerbaijan Muradov Sh. (Azerbaijan); Corresponding member of the NAS Republic of Azerbaijan Safarova Z. (Azerbaijan); Associate professor of Economics Vasilenko V.N. (Ukraine), Associate professor of Law Ustimenko V.A. (Ukraine)

News of the National Academy of Sciences of the Republic of Kazakhstan. Series of Social and Humanities. ISSN 2224-5294

Owner: RPA "National Academy of Sciences of the Republic of Kazakhstan" (Almaty)

The certificate of registration of a periodic printed publication in the Committee of information and archives of the Ministry of culture and information of the Republic of Kazakhstan N 10894-Ж, issued 30.04.2010

Periodicity: 6 times a year

Circulation: 500 copies

Editorial address: 28, Shevchenko str., of. 219, 220, Almaty, 050010, tel. 272-13-19, 272-13-18, www:nauka-nanrk.kz / social-human.kz

(C) National Academy of Sciences of the Republic of Kazakhstan, 2018

Address of printing house: ST "Aruna", 75, Muratbayev str, Almaty 
N E W S

OF THE NATIONAL ACADEMY OF SCIENCES OF THE REPUBLIC OF KAZAKHSTAN

SERIES OF SOCIAL AND HUMAN SCIENCES

ISSN 2224-5294

https://doi.org/10.32014/2018.2224-5294.5

Volume 5, Number 321 (2018), 33 - 38

UDK: 331.1

\author{
G.A. Abdullina ${ }^{1}$, A.G. Bazarbaeyev ${ }^{2}$ \\ 1,2 Narxoz University, Almaty city, Republic of Kazakhstan \\ E-mail: gulnar.abdullina@narxoz.kz, abzal.bazarbaev@narxoz.kz
}

\title{
MODERN CONCEPTS OF HUMAN RESOURCES MANAGEMENT IN ORGANIZATIONS
}

\begin{abstract}
The results of many recent studies have shown that managers often focus on production, financing and marketing, and that the company's key management system remains a weak link in human resource management. Human resources management systems used by organizations have significant shortcomings, and most importantly comprehensive monitoring of personnel activities, poorly developed information base, a clear system of personnel performance evaluation, outdated technology of forecasting personnel risks and much more. The article describes the main changes in personnel management in the development of society and labor relations, the essence and basic concepts of human resources management theory, functions and responsibilities of human resources management in organizations. Human resources management methodologies in organizations, global technological and structural changes, enterprise competitiveness and flexibility, and decentralization and privatization have led to the development of human resources management from human resources management to the evolution of production.
\end{abstract}

Key words: human resources, human resources management, organization.

\section{Introduction}

One of the priorities of the message of President of the Republic of Kazakhstan N.A. Nazarbayev to the people "New Opportunities for the Development during the Fourth Industrial Revolution" is human capital [1].

The term "human resources" is derived from the experience of the American College of Personnel Management. In the 70s of the 20th century, the concept of "personnel" and "personnel management" in the human resources management field in the United States was replaced by the concept of "human resources" and "human resource management". The concept of "human resources" reflects the role and place of man in the production, the adoption of new rules and regulations, the introduction of a number of innovations into many forms and methods of personnel work. The basic human resource management models developed in the United States at the end of the last century [2].

During the evolution of the theory of management in the 19th and 20th centuries, the role of people in the organization has undergone significant changes.

A. Smith has created a valuable labor theory. Bright representatives of this theory are D. Ricardo, later it was K. Marx. Hence, it was K. Marx who further developed the theory. He introduced the concept of "labor force", which he considers as a working ability [3].

Successful human resource management of the organization allows increasing labor productivity and maximizing profits. Due to the growing globalization trends in the global economy, the nature of human resource management is rapidly changing. Working with people from different countries makes it difficult for business to adapt to the current situation. As a result, new issues arise that need to be addressed within the international business environment.

The essence of the organization's activity is collective work of employees through the achievement of this goal. Management, planning, organization, motivation, coordination and monitoring are the basis of 
collective labor management. Because people are the basis of the driving force of any organization, the process of managing people plays an important role in the enterprise's overall governance.

The current stage of Kazakhstan's economic development is characterized by the need for competition between enterprises of national economies, competition for consumers, improvement of quality of goods and services and transition to innovative production.

The organization's human resources management system should be based on timely identification of potential problems and opportunities, based on their development plans, management and control over the human resources of the organization.

First of all, it is aimed at improving the quality of life, effectively utilizing the intellectual and physical capabilities of personnel management, strengthening labor relations in the organization, motivating and maximizing employee benefits [4].

Managing human resources has significantly changed in the development of society and labor relations. During the evolution of production, global technological and structural changes, competitiveness and flexibility of enterprises, as well as decentralization and privatization led to the development of personnel management from human resources to managing human resources.

It's worth to say that human resource management has long been established as a science. Initially, human resource management in science was considered and developed related to the production activities of different organizations [5].

At the same time, today there is a difference between theoretical justification and the development of human resources management tools identified as an important function of innovative development [6].

At the beginning of the 20th century principles of scientific organization of work were formed. The specific features of these principles are: orientation to individual worker; recruitment and training; distribution of labor, including the introduction of managerial activity; specialized human resources allocation.

Table 1-Evolution of human resources management approaches

\begin{tabular}{|c|c|c|}
\hline $\begin{array}{c}\text { The main directions of } \\
\text { management }\end{array}$ & Management relationships to employees & Human Resources Management \\
\hline 1 & 2 & 3 \\
\hline \multicolumn{3}{|l|}{ Until 1910} \\
\hline Industrial Technology & $\begin{array}{l}\text { Not looking indifferent to the needs of the } \\
\text { workers }\end{array}$ & Disciplinary systems \\
\hline \multicolumn{3}{|l|}{ From 1910 to 1920} \\
\hline Social security of employees & $\begin{array}{l}\text { Workers need safe working conditions and } \\
\text { opportunities for growth }\end{array}$ & $\begin{array}{l}\text { Safety guides, English lessons, curriculum } \\
\text { guidelines }\end{array}$ \\
\hline \multicolumn{3}{|l|}{ From 1920 to 1930} \\
\hline Effectiveness of tasks & $\begin{array}{l}\text { If workers increase productivity, workers } \\
\text { need higher wages }\end{array}$ & Study of movement during work and motion \\
\hline \multicolumn{3}{|l|}{ From 1930 to 1940} \\
\hline Personal differences & Accounting for personal differences & $\begin{array}{l}\text { Psychological testing and counseling for } \\
\text { employees }\end{array}$ \\
\hline \multicolumn{3}{|l|}{ From 1940 to 1950} \\
\hline Trade union movement & $\begin{array}{l}\text { Workers are the forces that can resist } \\
\text { leadership }\end{array}$ & $\begin{array}{l}\text { Employee communication programs, trade- } \\
\text { union methods }\end{array}$ \\
\hline \multicolumn{3}{|l|}{ From 1950 to 1960} \\
\hline Economic security & Employees need economic protection & $\begin{array}{l}\text { Personnel retirement plan, health plans, } \\
\text { discounts }\end{array}$ \\
\hline \multicolumn{3}{|l|}{ From 1960 to 1970} \\
\hline Human relationships & $\begin{array}{l}\text { Employees should take into account their } \\
\text { opinions when administering }\end{array}$ & $\begin{array}{l}\text { Professional training of managers (business } \\
\text { games, trainings, focusing on different } \\
\text { aspects) }\end{array}$ \\
\hline
\end{tabular}




\begin{tabular}{|c|c|c|}
\hline 1 & 2 & 3 \\
\hline Collective Decision-Making & $\begin{array}{l}\text { Employees are required to participate in } \\
\text { the decision-making process }\end{array}$ & $\begin{array}{l}\text { Methods of decision-making } \\
\text { management }\end{array}$ \\
\hline \multicolumn{3}{|l|}{ From 1980 to 1990} \\
\hline The problem is complicated & $\begin{array}{l}\text { Work is needed to meet the challenge and } \\
\text { comply with the abilities of employees }\end{array}$ & $\begin{array}{l}\text { Integrated groups of work enrichment, } \\
\text { problem solving and formation }\end{array}$ \\
\hline \multicolumn{3}{|l|}{ From 1990 to 2000} \\
\hline Personnel promotion & $\begin{array}{l}\text { Employees need jobs in the economic } \\
\text { crisis due to inter-country competition and } \\
\text { technology change }\end{array}$ & Development, retraining, restructuring \\
\hline \multicolumn{3}{|l|}{ From 2000 to 2010} \\
\hline $\begin{array}{l}\text { Changes in the composition of the } \\
\text { labor force and its shortfall }\end{array}$ & $\begin{array}{l}\text { Employees need flexibility, benefits, and } \\
\text { policies against them }\end{array}$ & $\begin{array}{l}\text { Strategic planning, employee rights, } \\
\text { professional training, flexible } \\
\text { discounts, computerization and more. }\end{array}$ \\
\hline \multicolumn{3}{|l|}{ From 2010 until now } \\
\hline $\begin{array}{l}\text { Personnel potential, human } \\
\text { (intellectual) capital development }\end{array}$ & $\begin{array}{l}\text { Guarantee of employment during the } \\
\text { financial crisis, human (intellectual) } \\
\text { capital assessment }\end{array}$ & $\begin{array}{l}\text { Intellectual Property Management, } \\
\text { Strategic Management of Employee } \\
\text { and Intellectual Property as a whole, } \\
\text { Planning and Assessment of Human } \\
\text { Capital }\end{array}$ \\
\hline
\end{tabular}

The School of Behavior created by Charles Bernard. Later followers of this school were F. Hertzberg, A. Maslow, D. He was MacGregor. The main purpose of this school was to increase the effectiveness of the organization's activities through the rational use of human resources. The theory of human resources is a new name given to this school based on that purpose.

It is important to note that human resources management has been shaped at the intersection of management, psychology, applied sociology, industrial sociology, ethics, business and business economics, labor law, politics, conflict theory and a whole range of other sciences.

Personnel Management is an organization that provides competitive professionals, their rational use, professional and social development. Searching, selecting and accepting worthy employees in the organization is the beginning of this service.

Human resource management is a new way of managing, which is "a strategic and consistent process of managing the entity's most valuable asset: the people working there affect collectively and individually to solve corporate issues" [7].

Moving from Personnel Management to Human Resources Management means moving from narrow specialization and limited liability to wider professional and work profiles; from a strictly planned career path to a flexible choice of professional development trajectory; and leads to full control over the employees' ability to promote personal development, creativity, and initiative.

We see that there are significant differences between personnel management and human resources management:

1) redirect personnel management system to individual work with the staff;

2) human resource management is of strategic importance that makes the personnel policy of the organization more active;

3) responsibility for the most active implementation of personnel policies lies on managers, i.e. the personnel work of all references managers is integrated into the personnel management system;

4) traditionally trying to save costs associated with modernization of managerial labor, human resource management technology is aimed at improving the effectiveness of such investments;

5) If in personnel management all attention is focused on simple staff, then human resource management focuses on managerial personnel;

6) The new personnel management system will adopt strong and adaptable corporate culture.

Human resource management envisages the transition from vertical organizational structures to transverse linkages and transition to organic structures, which is an important step in using the internal intellectual potential. Horizontal contacts have a great impact on the disclosure of creative potential of employees compared to vertical structures. 
Human resource management allows employees of the enterprises to create strong specialists, increase labor productivity, which will enable firms to develop competitive and sustainable growth in the long run.

However, managers do not use all the capabilities of managing these human resources, which leads to misuse of employees.

In the practice of modern management, the main concepts of human resources management have been formed with all the views, which are accepted equally with all modern managers. It is important to know the content and correctly interpret it.

The authors of the Human Resources Management textbook, Graham H. T. and Bennett R. note that the concept of "human resources management" is a comprehensive system that includes interconnected subsystems for the creation, use and development of human resources [8].

Mordovin S. K. sees the concept of "human resources management" as strategic and operational management aimed at improving the efficient use of human resources [9].

The main objective of human resources management is to develop the corporate capacity of the internal staff to achieve success through the use of human resources. The main objective of the company's employee's management is to work together in the group, to work as a percentage and to stick to employment.

The achievement of this goal will be focused on the following tasks:

- Purchasing and storing a company through qualified, generated and motivated workforce;

- maximal expansion and development of the internal capacities of the population by providing them with knowledge and professional development;

- Creation of favorable and harmonious partnership relations between managers of the company and their subordinates;

- balanced and developed approaches adapted to meet the needs of stakeholders (eg owners, senior executives, employees, suppliers, customers, federal, regional and municipal authorities, as well as the society as a whole);

- Appraisal of employees' performance and achievements and the use of effective methods of remuneration;

- managing diversity in labor collectives, employees' labor relations, behavior, and personal or group differences;

- creating conditions for the implementation of equal opportunities for all employees of the company;

In other words, the goal of human resource management is to hire, retain, encourage, improve and train qualified and motivated employees who can effectively implement the company's goals [10].

The main directions of effective human resource management in the current situation are: increase of motivation and self-motivation of employees; Improvement of the organizational structure of the enterprise; conducting a business valuation procedure and using its results in the selection and placement of human resources. Let's look at the directions.

There are many ways to classify motivation methods. The distribution of administrative, economic and socio-psychological stimulus is widespread. Administrative methods directly affect the person in the organization because they mean mandatory fulfilment of orders, instructions, tasks. They want a sense of debt, a desire to work in a particular organization, and so on. The process of material incentives is being accomplished by means of economic methods.

Human resources management is exercised through the entity's managing subjects - those directly involved in this activity.

Subjects of human resources: Managers of all levels; personnel service (HR) at the enterprise.

Given the importance of the staff, management is usually within the competence of the head of the organization or his first deputy. Senior management and managers at all levels are directly involved in staff management, which directly associates this function with the whole strategy of the organization. The efforts of these managers are aimed at engaging, selecting, propagating, stimulating, rationalizing, developing and retaining personnel for organizations that meet their needs and strategic goals [11].

The main purpose of the Personnel policy is to create an effective system of organization of personnel, administrative methods, as well as to achieve the highest employee productivity, and not just on economic incentives and social guarantees, but also to improve the productivity and achieve the best economic results.

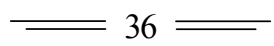


The main directions of the personnel policy of the organization are:

- marketing services in the field of personnel; Planning the organization's employees needs;

- Forecasting of creation of new workplaces taking into account introduction of new technologies;

- recruitment, selection, appraisal and evaluation of staff, organization of management and adaptation;

- recruitment and placement; stimulate and encourage incentive mechanisms to stimulate motivation and increase employee satisfaction;

- To make cost-effective staff expenses; development of human resources development programs, as well as future goals of the organization, not only today, but also by improving the training of personnel for promotion of education, career growth and managerial positions;

- organization of work and jobs;

- development of employment and social programs; efficient distribution and use of employees working in the organization, their rationalization;

- management of innovations in personnel work; ensuring safety and health of employees;

- analysis of reasons for dismissal of personnel and selection of the most effective options;

- ensuring high quality of work, life expectancy and labor results;

- development of projects for improving the management of the organization's employees and evaluation of socio-economic efficiency.

Human resources management should be part of the organization's development strategy to maximize the potential of the company's employees [12].

The managers of the late 20th century were ensuring the progressive development of the organization, the effective use of human resources, the creative power of the company's employees, continuous development and professional development of employees. However, there is a significant difference between the potential of employees and the extent of their use in the real world. This is due to the fact that managing human resources is still considered as a purely functional area of management of the organization, which has a weak relationship with the core business; HR staffs are not familiar with the organization's development strategy and cannot build a human resource management system that ensures the effective implementation of the strategy; The existing human resource management practices overlap the challenges facing the organization, hinder its employees' development and limit their share of organizational goals.

Thus, human resource management has not yet been fully used (ineffective) as a new approach to the company's operations in the management of enterprises.

The human resource management function of the organization is its own system with its principles, powers and functions. Expanding human resources management enables organizations to get more complete, accurate information about their employees and manage them more efficiently.

In conclusion, we can say that human resource management is now one of the key factors of the effectiveness of the organization's activities, mainly: achieving an active HR policy; Strategic role of human resources services and abstract functions in transition to system actions; integration of human resource planning into corporate planning; emphasis is placed on human capital change and investment.

\section{REFERENCE}

[1]www.akorda.kz Қаzақstan Respublikasi Prezidentiniң resmisaiti.

[2] Shaburova A.V. Upravlenie vosproizvodstvom kachestvennih trudov ih resursov neftegazodobivayuschih predpriyatii Zapadnoi Sibirimonografiya. Novosibirsk 2014.

[3]Golubev K.I. Istoriya menedjmenta tendenciy agumanizacii SPb 2003.

[4]Vesnin V.R. Upravlenie personalom. Teoriya i praktikauchebnik 2011.

[5]Sokolova M. I. Upravlenie chelovecheskimi resursami uchebnik 2007.

[6]Kuzes D.M. Vizovliderstva per. s angl. 2009.

[7]KibanovA.Ya. Novaya stadiya evolyucii nauk i ob upravlenii personalomprineizmennoiparadigme 2014. №5 41.

[8]Grehem H.T. Upravleniechelovecheskimiresursami 2006.

[9]Mordovin S. K. Upravlenie chelovecheskimi resursami 17 modulnay aprogramma dlya menedjerov «Upravlenie razvitie morganizacii. Modul 16» 2000.

[10]Balashov A. I. Upravlenie chelovecheskimi resursami uchebnoe posobie SPb. Piter 2012.

[11]Pugachev V. P. ZnakomtesUChR -2009. №2.

[12]Shekshnya S. V. Upravlenie personalom sovremennoi organizacii uchebnopraktiches koeposobie ZAO «Biznesshkola» Intel Sintez» 1998. 
УДК: 331.1

\author{
Г.А. Абдулина ${ }^{1}$, А.Г. Базарбаев ${ }^{2}$ \\ 1,2 «Университет Нархоз» АҚ, Алматы қ., Қазақстан Республикасы
}

\title{
ҰЙЫМДАРДАҒЫ АДАМ РЕСУРСТАРЫН БАСКАРУДЫҢ ЗАМАНАУИ ТҰЖЫРЫМДАМАЛАРЫ
}

Аннотация. Соңғы жылдардағы көптеген зерттеулердің нәтижелері ұйымдардың басшылары көбінесе өндірісті, қаржыландыруды және маркетингті басқаруға назар аударады, бұл ретте кәсіпорынның маңызды басқару жүйесі адам ресурстары басқаруды әлсіз байланыс болып қала береді. Ұйымдар пайдаланатын адам ресурстарын басқару жүйелері елеулі кемшіліктерге ие, олардың бастысы, персоналдың іс-әрекеттеріне кешенді мониторинг жүргізу, нашар дамыған ақпараттық база, персоналдың тиімділігін бағалаудың айқын жүйесі, персонал тәуекелдерін болжауға арналған ескірген технологиялар және басқалар. Мақалада қоғам мен еңбек қатынастарын дамыту процесінде персоналды басқару айтарлықтай өзгергендігі, ұйымның адам ресурстарын басқару теориясының мәні мен негізгі ұғымдары, ұйымдардағы адами ресурстарды басқарудағы кадрлық қызметтің функциялары мен міндеттері сипатталған. Ұйымдарда адам ресурстарын басқару проблемаларын зерттеудің әдістемелік тәсілдері, өндірістің эволюциясы барысында жаһандық технологиялық және құрылымдық өзгерістер, кәсіпорындардың бәсекеге қабілеттілігі мен икемділігі, сондайақ орталықсыздандыру және жекешелендіру персоналды кадрлық басқарудан адам ресурстарын басқаруға дейін дамытуға әкелгендігі қарастырылған.

Түйін сөздер: адам ресурстары, адам ресурстарын басқару, ұйым.

$$
\begin{gathered}
\text { Г.А. Абдулина }{ }^{1} \text {, А.Г. Базарбаев }{ }^{2} \\
{ }^{1,2} \text { АО «Университет Нархоз», г. Алматы, Республика Казахстан }
\end{gathered}
$$

\section{СОВРЕМЕННЫЕ КОНЦЕПЦИИ УПРАВЛЕНИЯ ЧЕЛОВЕЧЕСКМИ РЕСУРСАМИ В ОРГАНИЗАЦИЯХ}

Аннотация. Результаты многих недавних исследований показали, что менеджеры часто сосредотачиваются на производстве, финансировании и маркетинге, а ключевая система управления компанией остается слабым звеном в управлении человеческими ресурсами. Системы управления людскими ресурсами, используемые организациями, имеют значительные недостатки, а самое главное - комплексный мониторинг кадровой деятельности, слабо развитая информационная база, четкая система оценки эффективности персонала, устаревшая технология прогнозирования рисков персонала и многое другое. В статье излагаются основные изменения в управлении персоналом в развитии общества и трудовых отношениях, сущность и основные концепции теории управления людскими ресурсами, функции и обязанности управления человеческими ресурсами в организациях. Методологии управления людскими ресурсами в организациях, глобальные технологические и структурные изменения, конкурентоспособность и гибкость предприятий, а также децентрализация и приватизация привели к развитию управления людскими ресурсами от управления людскими ресурсами до эволюции производства.

Ключевые слова: человеческие ресурсы, управление человеческими ресурсами, организация.

Information about author:

Abdullina G.A. - Narxoz University, Almaty city, Republic of Kazakhstan, gulnar.abdullina@narxoz.kz, https://orcid.org/0000-0002-7685-5190;

Bazarbaeyev A.G. - Narxoz University, Almaty city, Republic of Kazakhstan’ E-mail: abzal.bazarbaev@narxoz.kz 


\section{МАЗМҰНЫ}

Алтыбаева С.М., Савындыков Е.С. Көркем мәтін құрылымындағы мифопоэтикалық модельдеу және мәдени код...... 5 Сембиева Л.М., Мажитов Д.М., Карпиикая М.Е., Хамитова Д.М. Экономиканы жаңғырту жағдайындағы ЕАЭО елдерінің монетарлық жүесінін өзгеруі .....

Құлсариева А.Т., Султанова М.Э., Шайгозова Ж.Н. Фольклор және сәйкестілік: Қазақстанның қазіргі заманғы

мәдениетіндегі тарих, жады және аңыз шығармашылығы ........................................................................................... 19

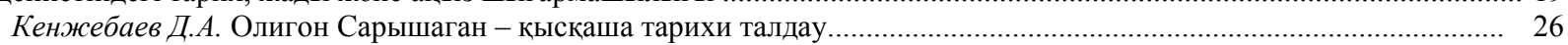

АбдулинаГ.А., БазарбаевА.Г. Ұйымдардағы адам ресурстарын басқарудың заманауи тұжырымдамалары................ 33

Авыбаев А.Н., Адибаева А.К. Геноцид туралы БҰҰ Конвенциясының қатысушы мемлекеттердің қылмыстық

заңнамаларындағы имплементациялық тетіктері: жалпы салыстырмалы талдау............................................................ 39

Ахметжанов Б., Тәжібекова К.Б., Шаметова А.А. Қазақстан көлік өнеркәсіптің дамуын талдау............................. 44

Аюпова 3.К., Құсайынов Д.Ө. Тәуелсіздік жағдайындағы қазақстан республикасының конституциялық-құқықтық

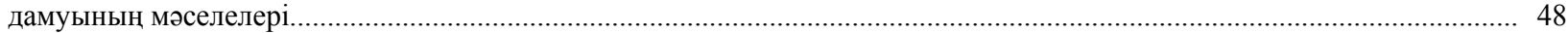

Нурпеисова А.А., Рей И.Ю., Бижанов Д.Т., Тлеужанова Д.А. Инновациялық өндірісді жасаудың процесін

бақылауының негізгі элементтері

Гиздатов Г.Г. Қазақстандық дискурсының құрылымы психолингвистиякалық зерттеу .

Ищанова Р.К. Мемлекеттік шығындарды басқару - мемлекеттің қаржылық тұрақтылығын қамтамасыз ету.............. 64

Мадышева А.М. Бикенова А.С., Елеусиз Л.Т. Білім саласындағы туристік қызметтер............................................. 68

Ескалиева А. Ж., Баймуханова М.Т., Ахмурзина Д.О. Әлеуметтік сала адам капиталының сапасын қолдаудың

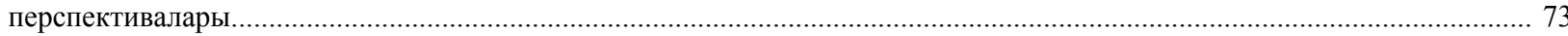

Мархаева Б.А., Козбахова Д.Л. Жауапкершілік орталық және трансферттік баға белгілеу............................................ 79

Сабирова Р.К., Утепкалиева К.М., Кабаков С.Б. Қазақстандағы ауыл шаруашылығы экономикасының

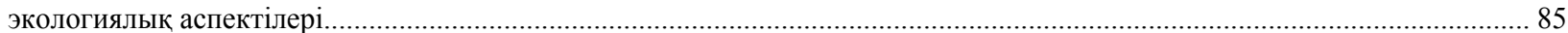

Тлесова Э., Хойч А., Кураш Н. Қазақстан республикасының ғылыми инновациялық потенциясы және оның

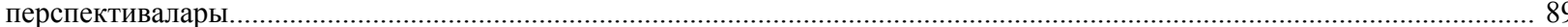

Хамитхан Н. Қазақстандағы банктік қызметтердің сапасын жақсарту жағдайында банкаралык басекелестік............ 95

Шалдарбеков Қ.Б., Муханова Г.С., Нурмухамбетова 3.С. Аймақтарды дамыту бағдарламаларын жүзеге асырудағы жобалық басқаруды қолданудың шетелдік тәжірибесі

КаратаеваА.М., Бердиярова Ж.С. Мемлекеттік қызметшінің әдептік мәдениеті және құқықтық мәдениеті

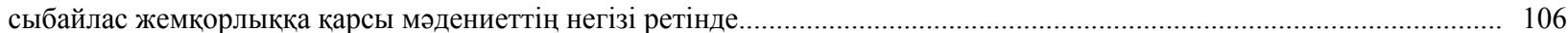

Алдабергенова А.А. Абсурд әдебиетін аударудың лингвомәдени аспектілері ................................................... 113

Стукач В. Ф., Байдалинова А. С., Сандыбаева Б. А. Қазақстанның қаржылық қауіпсіздігі......................................... 119

Баймаханова Д.М., Оспанова Д.А. Конституциялық-құқықтық сана - конституционализмнің маңызды

компоненті ретінде және оның адам құқықтары мәселелерін шешудегі рөлі................................................................. 126

Имангожина 3.А. Сланцевая революция: глобальный тренд на мировом энергетическом рынке............................. 137

Ракаева А.Н., Жуматаева Б.А., Успамбаева М.К., Доскалиева Б.Б. Экологиялық есеп қазақстандағы кәсіпорын экономикасының даму кезеңі ретінде

Нуржанова Г.И. Экономиканың аграрлық секторындағы еңбек әлеуетіне демографиялық фактордың әсері............ 147

Оспанова Д.А., Баймаханова Д.М. Қазақстан Республикасының кибер кеңістігін дамыту жағдайында мемлекеттік қызметтерді цифрландыруда әкімшілік-құқықтық қамтамасыз ету ................................................................................... 152

Pblсnекова М.О., Тлесова Э.Б., Хаитбаева Ф.К. Қазақстандағы тұрғын үй-коммуналдық шаруашылық қызметін

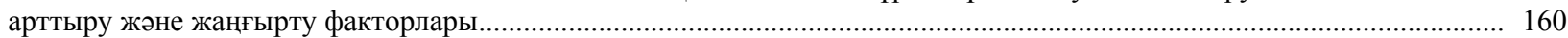

Султанова Г. Т. Аграрлық сектордың экспорттық әлеуетін дамытуға бағытталған үрдістер мен басымдықтар........ 166 


\section{СОДЕРЖАНИЕ}

Алтыбаева С.М., Сагындыков Е.С. Культурный код и мифопоэтическое моделирование в структуре художественного текста

Сембиева Л.М., Мажитов Д.М., Карпиикая М.Е., Хамитова Д.М. Трансформация монетарной системы стран

ЕАЭС в условиях модернизации экономики

Кулсариева А.Т., Султанова М.Э., Шайгозова Ж.Н. Фольклор и идентичность: история, память и мифотворчество

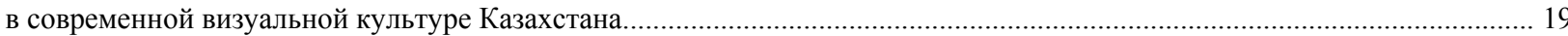

Кенжебаев Д.А. Полигон Сарышаган - краткий исторический анализ................................................................ 26

Абдулина Г.А., БазарбаевА.Г. Современные концепции управления человеческми ресурсами в организациях............ 33

Агыбаев А.Н., Адибаева А.К. Имплементационные механизмы Конвенции ООН о геноциде в уголовных

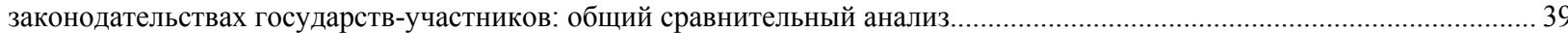

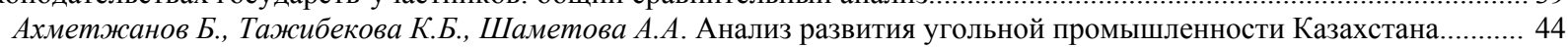

Аюпова 3.К., Кусаинов Д.У.Проблемы конституционно-правового развития республики Казахстан в условиях суверенитета ......

Нурпеисова А.А., Рей И.Ю., Бижанов Д.Т., Тлеужанова Д.А. Основные элементы управления процессом создания инновационной продукции ....

Гиздатов Г.Г. Психолингвистическое исследование концептов казахстанского дискурса......

Ищанова Р.К. Управление государственными расходами - как обеспечение финансовой устойчивости государства. 64

Мадышева А.М. Бикенова А.С., Елеусиз Л.Т. Туристские услуги в сфере образования................................................. 68

Ескалиева А. Ж., Баймуханова М.Т., Ахмурзина Д.О. Перспективы усиления качества человеческого капитала

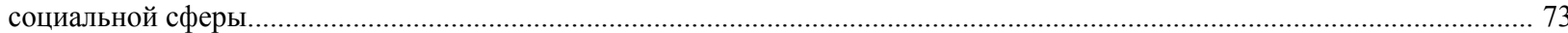

Мархаева Б.А., Козбахова Д.Л. Центр ответственности и трансфертное ценообразование....................................... 79

Сабирова Р.К., Утепкалиева К.М., Кабаков С.Б. Экологические аспекты экономики сельского хозяйства

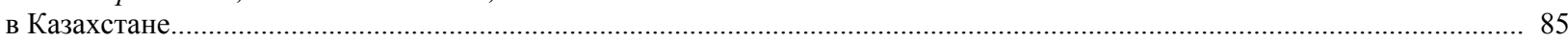

Тлесова Э., Хойч А., Кураш Н. Научно-инновационный потенциал республики Казкастан и его перспективы............ 89

Хамитхан Н. Межбанковская конкуренция в условиях повышения качества банковских услуг в Казахстане..............95

Шалдарбеков К.Б., Муханова Г.С., Нурмухамбетова З.С. Зарубежный опыт применения проектного управления

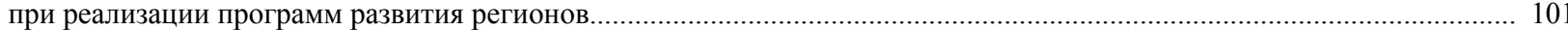

Каратаева А.М., Бердиярова Ж.С. Этическая культура и правовая культура государственных служащих

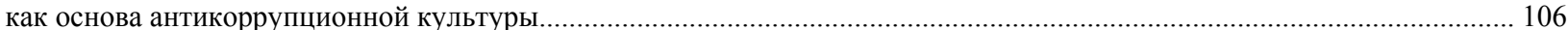

Алдабергенова А.А. Лингвокультурологические аспекты перевода литературы абсурда........................................... 113

Стукач В. Ф., Байдалинова А. С., Сандыбаева Б. А. Казахстанская финансовая безопасность................................... 119

Баймаханова Д.М., Оспанова Д.А. Конституционно-правовое сознание как важный компонент конституционализма

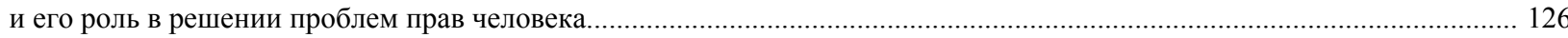

Имангожина 3.А. Сланцевая революция: глобальный тренд на мировом энергетическом рынке............................ 137

Ракаева А.Н., Жуматаева Б.А., Успамбаева М.К., Доскалиева Б.Б. Экологический учет как ступень развития

экономики предприятия в Казахстане............................................................................................

Нуржанова Г.И. Влияние демографического фактора на трудовой потенциал аграрного сектора экономики............ 147

Оспанова Д.А., Баймаханова Д.М. Административно-правовое обеспечение цифровизации государственных услуг в условиях развития кибер пронстранства республики Казахстан......

Рыспекова М.О., Тлесова Э.Б., Хаитбаева Ф.К. Факторы инновационной модернизации и совершенствования деятельности жилищно-коммунального хозяйства в Казахстане

Султанова Г. Т. Тенденции и приоритеты развития экспортного потенциала аграрного сектора... 


\section{CONTENTS}

Altybayeva S.M., Sagyndykov E.S. Cultural code and myth poetic modeling in the structure of the artistic text..................... 5 Sembiyeva L.M., Mazhitov D.M., Karpitskaya M.E., Khamitova D.M. Transformation of the monetary system of the eurasian economic UNION countries in the conditions of modernization of the economy......

Kulsarieva A.T., Sultanova M.E., Shaigozova Zh.N. Folklore and identity: history, memory and myth-making in the modern

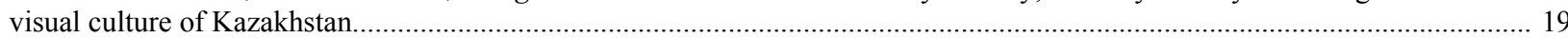

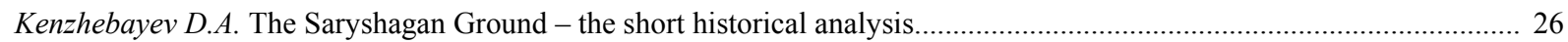

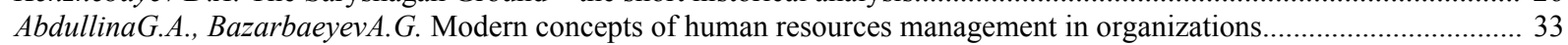

Agybayev A.N., Adibayeva A.K. Implementing mechanisms of the UN Convention on genocide in the criminal legislation

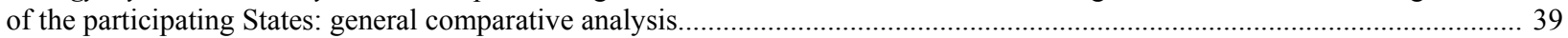

Akhmetzhanov B., Tazhibekova K.B, Shametova A.A. Analysis of development of the coal industry of Kazakhstan.............. 44 Ayupova Z.K., Kussainov D.U. Problems of constitutional and legal development of the republic of kazakhstan in the conditions of sovereignty......

Nurpeisova A.A., Rey I.Yu., Bizhanov D.T., Tleuzhanova D.A. Main elements of managing the process of creating innovation production.

Gizdatov G.G. Psycholinguistic study of the concepts of Kazakhstar

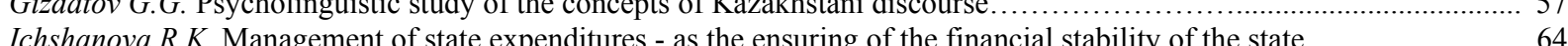

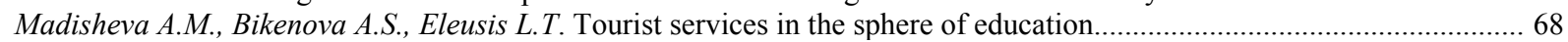

Eskalieva A. Zh., Baymukhanova M.T., Ahmurzina D.O. Perspectives of strengthening the quality of the human capital

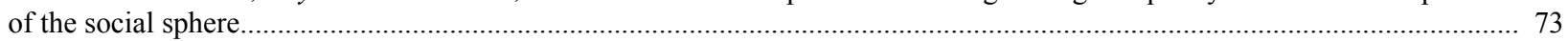

Markhayeva B.A., Kozbakhova D.L. A responsibility center and transfer pricing ................................................. 79

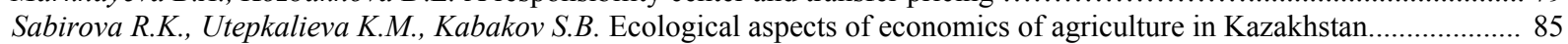

Tlessova E., Khoich A., Kurash N. Scientific innovation potential of the republic of Kazkahstan and its perspectives........ 89

Hamitkhan $N$. Interbank competition in conditions of improving the quality of banking services in Kazakhstan.................. 95

Shaldarbekov K., Mukhanova G., Nurmukhambetova Z. International practices in project management in implementing

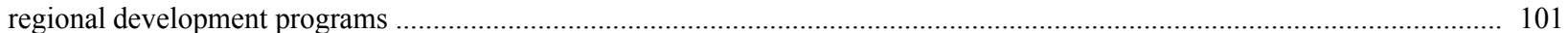

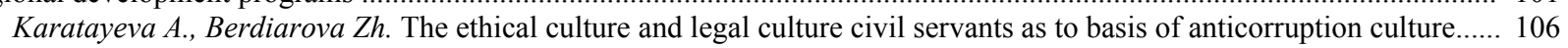

Aldabergenova A.A. Linguocultural aspects of translation of absurd literature.............................................................. 113

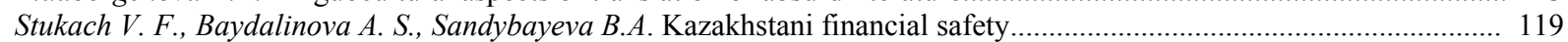

Baimakhanova D.M., Ospanova D.A. Constitutional and legal consciousness as an important component of constitutionalism

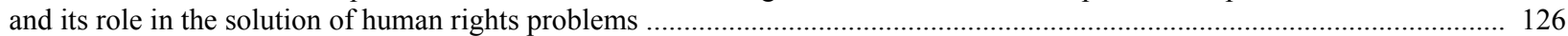

Imangozhina Z.A. Shale gas revolution: global trend in the world energy market..................................................... 137

Rakaeva A.N., Zhumataeva B.A., Uspanbayeva M.K., B.B.Doskalieva. Level of ecological report development in the economic of Kazakhstan's companies.

Nurzhanova G.I. Impact of demographic factors on labor potential of economy's agricultural sector

Ospanova D.A., Baimakhanova D.M. Administrative and legal support of digitalization of public services in the context of the development of cyber space in the republic of Kazakhstan....

Ryspekova M.O., Tlessova E.B., Khaitbayeva F. Factors of innovative modernization and improvement of activity

of housing and communal services in Kazakhstan.

Sultanova G. T. Trends and priorities for the development of export potential of the agrarian sector. 


\title{
PUBLICATION ETHICS AND PUBLICATION MALPRACTICE IN THE JOURNALS OF THE NATIONAL ACADEMY OF SCIENCES OF THE REPUBLIC OF KAZAKHSTAN
}

For information on Ethics in publishing and Ethical guidelines for journal publication see http://www.elsevier.com/publishingethics and http://www.elsevier.com/journal-authors/ethics.

Submission of an article to the National Academy of Sciences of the Republic of Kazakhstan implies that the work described has not been published previously (except in the form of an abstract or as part of a published lecture or academic thesis or as an electronic preprint, see http://www.elsevier.com/postingpolicy), that it is not under consideration for publication elsewhere, that its publication is approved by all authors and tacitly or explicitly by the responsible authorities where the work was carried out, and that, if accepted, it will not be published elsewhere in the same form, in English or in any other language, including electronically without the written consent of the copyrightholder. In particular, translations into English of papers already published in another language are not accepted.

No other forms of scientific misconduct are allowed, such as plagiarism, falsification, fraudulent data, incorrect interpretation of other works, incorrect citations, etc. The National Academy of Sciences of the Republic of Kazakhstan follows the Code of Conduct of the Committee on Publication Ethics (COPE), and follows the COPE Flowcharts for Resolving Cases of Suspected Misconduct (http://publicationethics.org/files/u2/New Code.pdf). To verify originality, your article may be checked by the originality detection service Cross Check http://www.elsevier.com/editors/plagdetect.

The authors are obliged to participate in peer review process and be ready to provide corrections, clarifications, retractions and apologies when needed. All authors of a paper should have significantly contributed to the research.

The reviewers should provide objective judgments and should point out relevant published works which are not yet cited. Reviewed articles should be treated confidentially. The reviewers will be chosen in such a way that there is no conflict of interests with respect to the research, the authors and/or the research funders.

The editors have complete responsibility and authority to reject or accept a paper, and they will only accept a paper when reasonably certain. They will preserve anonymity of reviewers and promote publication of corrections, clarifications, retractions and apologies when needed. The acceptance of a paper automatically implies the copyright transfer to the National Academy of sciences of the Republic of Kazakhstan.

The Editorial Board of the National Academy of sciences of the Republic of Kazakhstan will monitor and safeguard publishing ethics.

Правила оформления статьи для публикации в журнале смотреть на сайте:

$$
\begin{gathered}
\text { www:nauka-nanrk.kz } \\
\text { social-human.kz }
\end{gathered}
$$

\author{
Редакторы М.С. Ахметова, Т.А. Апендиев, Д.С. Аленов \\ Верстка на компьютере А.М. Кульгинбаевой \\ Подписано в печать 10.10.2018 \\ Формат 60x881/8. Бумага офсетная. Печать - ризограф. \\ 11,6 п.л. Тираж 500. Заказ 5.
}

